\title{
EGFR NP_005219.2:p.G719V
}

National Cancer Institute

\section{Source}

National Cancer Institute. EGFR NP 005219.2:p.G719V. NCI Thesaurus. Code C98529.

A change in the amino acid residue at position 719 in the epidermal growth factor receptor protein where glycine has been replaced by valine. 